\title{
СОЦІАЛЬНО-ПОБУТОВА ПІСЕННІСТЬ ЗАРОБІТЧАНСЬКОЇ ТЕМАТИКИ: ДИНАМІКА ТРАДИЦІЇ ТА НАЦІОНАЛЬНА МЕНТАЛЬНІСТЬ
}

Мельник Н. Г. Соціально-побутова пісенність заробітчанської тематики: динаміка традиції та національна ментальність.

У статті досліджуються особливості вияву традиційних поглядів людини на життя в соціально-побутовій пісенності заробітчанської тематики та їх трансформації під впливом соціально-економічних чинників. Особлива увага приділяється проблемі зміни складових рис національної ментальності українців у залежності від суспільно-історичних умов. Ключові слова: традиція, ментальність, фольклор, заробітчанство, тематика.

Ключові слова: традиція, ментальність, фольклор, заробітчанство, тематика.

Мельник Н. Г. Социально-бытовая песенность рабочей тематики: динамика традиции и национальная ментальность.

В статье исследуются особенности выражения традиционных взглядов человека на жизнь в социально-бытовой песенности рабочей тематики, их трансформации под влиянием социально-економических причин. Особенное внимание уделяется проблеме смены особенностей национальной ментальности украинцев в зависимости от социально-исторических условий.

Ключевые слова: традиция, ментальность, фольклор, заработчанство, тематика.

Melnyk N. G. Socio-home melodiousness migrant workers themes: the dynamics of tradition and national mentality.

This article analyzes the manifestation of traditional attitudes to life in the sociohome melodiousness migrant workers themes and their transformation under the influence of socio-economic factors. Particular attention is given to changes in the components of the national rice Ukrainian mentality depending on the social and historical conditions.

Key words: tradition, mentality, folklore, migrant workers, themes.

Здобуття незалежності Україною поставило перед сучасними вченими ряд важливих завдань, пов'язаних із розбудовою молодої держави на основі українських народних традицій та відповідно до особливостей національної ментальності, сформованих у процесі історичного розвитку.

Останні десятиліття відзначаються посиленням інтересу суспільства до етнокультурної спадщини українського народу, зверненням до фольклорних джерел, характеризуються прагненням зрозуміти свою національну вдачу, зберегти та розвинути в руслі традиції матеріальний та духовний досвід нації. 
У цьому сенсі надзвичайно перспективним є вивчення соціальнопобутової фольклорної спадщини українського народу, іiі зв'язку 3 традицією та національною ментальністю.

Загальновідомо, що фольклорний процес обов'язково набуває характеру руху всередині традиції, іiі еволюції та трансформації, тому на кожному відрізку часу фольклор $є$ динамічною системою й відображає певний стан традиції.

Традиція є системою, що забезпечує зв'язок сьогодення 3 минулим, втілює досвід колективу, суспільства, яке прагне до накопичення історичних, культурних, художніх надбань народу. Тому визначення традиційних ознак соціально-побутового фольклору, дослідження трансформацій, що відбулися під впливом історичних, політичних, психологічних умов життя українського народу, різних пластів традиційно-побутової культури є надзвичайно потрібним.

Дослідження відображених у фольклорі засад української національної ментальності як психокультурного образу нації, сукупності визначальних національних рис, уявлень народу про самого себе, стереотипів поведінки, що передаються 3 покоління в покоління $\epsilon$ сьогодні надзвичайно актуальним з огляду на ії (ментальності) здатність зберігати в закодованій формі історичний досвід народу та визначати його подальший суспільний розвиток. Врахування характерних рис та особливостей національної ментальності $€$ необхідною умовою реформування українського суспільства.

Окремі проблеми, пов'язані з жанровою специфікою фольклорних творів соціально-побутового змісту, їх виникненням та побутуванням, стали предметом досліджень М. Костомарова, М. Драгоманова, I. Франка, М. Сумцова, Б. Грінченка, М. Максимовича, Ф. Колесси, О. Потебні, О. Дея, Г. Нудьги, Н. Шумади, В. Скрипки, Р. Кирчіва, С. Грици, О. Правдюка, С. Мишанича, О. Хмілевської, Л. Дунаєвської, М. Дмитренка, Л. Вахніної. Великий внесок в дослідження сутності ментальності зробили В. Антонович, М. Драгоманов, М. Костомаров, О. Потебня, I. Франко, М. Грушевський, Д. Донцов, В. Липинський, М. Міхновський, Г. Ващенко, І. Мірчук, В. Янів.

Сьогодні постала необхідність комплексного аналізу фольклорної спадщини соціально-побутової тематики, відображення в народних творах названої спрямованості традиційних ознак та провідних складових національної ментальності українців.

У розгалуженій системі фольклору твори соціально-побутового 
змісту займають чільне місце, адже вони є результатом постійного розвитку національно-суспільної свідомості, відображенням культури соціально-побутових відносин. Народ століттями зберігає традиційні зразки, а виникнення нових соціальних груп у процесі розвитку суспільних відносин спричиняє появу нових творів, що відображають явища суспільного життя та народне ставлення до них. Фольклор живе, розвивається з розвитком нації.

Отже, на часі перспективним та науково вмотивованим для фольклористичного пошуку $є$ звернення до фольклорної спадщини соціально-побутового спрямування, визначення жанрової специфіки творів, динаміки традиції та ознак національної ментальності досліджуваного пласту фольклору.

Одним із найяскравіших циклів соціально-побутової тематики 3 точки зору відображення в них трансформації засад національної ментальності є заробітчанська пісенність.

Дослідники фольклору визначають характер заробітчанської пісні як психологічно-філософський, адже народ у своїй творчості не лише визначає соціальні причини тяжкого становища особистості, змушеної працювати на інших, але й засвідчує ті зміни, які відбулися в психіці людини та іï концепції дійсності. Так, фольклористи помітили, що «давні бурлацькі пісні мають у змісті і формі багато спільного 3 козацькими та чумацькими піснями <..> У давніх бурлацьких піснях відчувається дух людей мужніх, бувалих, непокірних, що зневажають життєві незгоди [1, с. 11]. Проте, під впливом посилення експлуатації, соціального розшарування «прагнення до свободи, відображені народною пісенністю, починають заступатись відчуттям непевності, пригнобленого становища» [1, с. 11].

Хронологічно явище заробітчанства розквітає у другій половині XIX - на початку XX ст. Спочатку наймаються на роботу безземельні та зубожілі селяни, утікачі від поміщиків, пізніше, із розвитком фабрик, заводів, цукроварень застосування найманої праці неухильно зростає.

С. Грица констатує: «Якнайтісніше пов'язана 3 трудовими процесами, заробітчанська пісенність чутливо реагувала на зміни у виробничих і суспільних відносинах. Тим-то іï найновіші нашарування пореформеного часу, що помітно відійшли від традиційної селянської основи, стали своєрідним явищем у розвитку народної творчості» [1, с. 9].

Заробітчанська пісенність традиційно поділяється на: 1) пісні, 
що зображують долю наймита, бурлака; 2) твори, які змальовують долю заробітчанина на бурякових, тютюнових плантаціях, заводах та фабриках; 3) емігрантські пісні.

Генетично найдавнішою гілкою заробітчанської народної поезії вчені вважають бурлацькі пісні [1, с. 11].

Виникнення соціальної групи бурлаків історики та соціологи пов'язують ще $з$ давньоруським періодом історії східних слов'ян, коли мандрівні люди-заробітчани, добуваючи сіль у Прикарпатті та Карпатах привозили ії у Київську Русь.

Науковці також зазначають, що «як одна 3 найдавніших форм заробітчанства на Україні, заснована на правах вільного найму, бурлацтво XVI-XVIII ст. було тісно пов'язане 3 визвольними селянськими рухами. Тому народна поезія, в якій нерідко виступають поряд образи козака, чумака, бурлаки, засвідчує спільність їх інтересів на певному історичному етапі, їхні вільнодумні настрої» [1, с. 11].

Справді, давніші бурлацькі пісні ідейно близькі до козацьких. У них відображені почуття, настрої особистості, яка має власну гідність і небайдужа до долі своєї батьківщини. Пізніші ж твори ілюструють запанування настроїв пригніченості, песимізму, примирення 3 долею злидаря i нещасної людини, малюють картини морального приниження бурлака, репрезентують прагматичний, позбавлений високих ідеалів, погляд на життя. Отже, можна говорити про трансформацію традиційних уподобань народу, зміну життєвої концепції людини під впливом соціально-економічних чинників.

Часто пісня починається констатацією: «нема гірше так нікому...» або «нема в світі так нікому». Життя бурлака, на думку народу, вже запрограмоване на недолю: Доле ж моя, доле, та доле ж моя злая! Та доле ж моя злая, чом ти не такая, Чом ти не такая, як доля людськая? Що люди не роблять, та в жупанах ходять, А я роблю, дбаю - нічого не маю! [2, с. 48]; Ой доля людская єсть сліпая, Бо служить негідним і їм помагає. Добре терплять нужду, по миру товчуться, Та все не в лад прийде, за що не візьмуться [2, с. 50]; Виріс я в наймах, в неволі Та не знав я долі ніколи. Гей, гей! По дорогах ходючи Та чужії воли пасучи [2, с. 54].

Мотиви залежності життя бурлака від долі, даної при народженні, численні й розмаїті. Вона наділяє людину певними рисами характеру, визначає рівень матеріальної забезпеченості, впливає на можливість створення сім’ї людиною, прогнозує успіх у роботі. Наприклад: Чом 
соловей не щебече - Голосу не має. Чом бурлака не жениться - Бог долі не дає [2, с. 52]; Ой а бурлак як затуже, Що фортунонька не служе [2, с. 49].

Поряд із цим, за народним баченням, незалежно від даної Богом, матір'ю долі, людина повинна сама обирати свій життєвий шлях. Народ досить тонко розрізняє причини того, чому бурлак, наймит, сирота погоджуються на тяжку підневільну працю на іншого. Часто нещастя, бідність бурлака розуміються народною свідомістю як розплата на аморальний, негідний спосіб життя: Озвалася доля, за плечима стоя: - Чумаче-бурлаче! Не винувата доля, Не винувата доля, винувата твоя воля, Що ти п'єш-гуляєш - нічого не маєш [2, с. 49]; - Козаче-бурлаче! Дурний розум маєш, Що ти свою долю марне проклинаєш! Ой не винна доля, винна твоя воля - Що ти заробляєш, те все пропиваєш, Що вдень загорюєш, за ніч прогайнуєш, А щзо заталаниш, то музики наймаєш [2, с. 48].

Фольклорна пам'ять відображає життєві ситуації, коли бурлак стикається 3 нерозумінням оточення, неадекватною оцінкою його справжньої сутності. Оскільки поведінка представника цієї соціальної групи випадає 3 традиційних, сформованих селянським середовищем, уявлень про нормальне життя, вона викликає переважно негативні оцінки громади. Стереотипні уявлення про бурлака як гультяя іноді переважають над об'єктивним аналізом ситуації: Та бурлак робить $i$ горує, Люди кажуть: «n'є, гайнує» Та бурлак робить, роботає, Аж nіт очі заливає. Та бурлак робить, з ніг валиться, Люди кажуть: «він упився» [2, с. 55]; Да прийшов бурлак до корчмоньки, Та на стіл похилився. Кажуть люди й рідне браття: Ледачий упився [2, с. 48].

Часто фізичні та духовні страждання формують у свідомості людини бажання вмерти. Не маючи сили для протесту, бурлак вбачає порятунок від становища раба у смерті: Бурлак ноги підгинає Та й на небо поглядає: - Та подай, боже, з неба смерти, Пора бурлаку умерти [2, с. 54].

Нестерпне становище, що змушує людину просити смерті, відображено i в пізніших зразках заробітчанського фольклору. Народні твори, що виникають в період активного шахтобудування на Криворіжжі, містять близькі до вищеназваних мотиви: $O x$ mu, шахто моя, Шахто чорная, Шахто чорная, Забери ж ти мене. Ой візьми ж ти мене, Та накрий ти мене, Та накрий ти мене Смертю чорною [Iз матеріалів фольклорної практики студентів факультету української філології КПІ ДВНЗ «КНУ»].

() Н. Г. Мельник, 2012. 
Іноді народна пісня демонструє глибоке розуміння причин того, що на рідній землі людина не може бути щасливою, вказує на чинники політичного характеру. У таких творах яскраво проілюстровано осмислення бурлацтва як логічного продовження козацтва 3 його патріотичними ідеалами; розчарування, пов'язаного 3 теперішньою національною ситуацією на Україні: Tu, цุарице Катерино, Що ти наробила! Край веселий, гай зелений Панам роздарила! Багатому розпродала Від краю до краю, А бідному зоставила Те, де поховають. Бо ичариця Катерина Добре в карти грала, Вона наше усе добро Та й попрогравала. А ти, графе, ти, Потоцький, Розпроклятий сину, Занапастив свою Польщу Та й взяв Україну. Думав, було, на Вкраӥні, Щоб королем стати! Пропадай ти $i$ сам тепер Та ще й твоя мати. Грайте котрий на сопілку - Сумно так сидіти! Що діється тепер в світі Да чиї ж ми діти? [2, с. 53].

Отже, зразки бурлацької пісенності ілюструють народне ставлення до невільницького життя, а також репрезентують уявлення про долю людини-заробітчанина. Неволя в будь-якому виявленні не приймається національною свідомістю, хоча шляхи іiі уникнення різняться в залежності від часу та середовища, в якому виник твір.

Наймитський та сирітський цикли соціально-побутової пісенності близькі до бурлацького за своїм змістом та ідейною спрямованістю. Доля наймита, сироти - безперспективна. Найчастіше вони позбавлені можливості жити щасливо від народження, іноді втрачають захист фортуни після прокльонів матері або внаслідок негідної поведінки. ставленні до наймита, сироти також з одного боку спостерігаємо співчуття, 3 іншого - натрапляємо на досить критичну оцінку його способу життя.

Народне осмислення ролі та поведінки названих соціальних типів підпорядковане побутуванням архетипних традиційних уявлень про суспільну значимість особистості, які сформувалися в козацькому середовищі. Прямо чи опосередковано в народній творчості кожен образ чоловіка зіставляється, порівнюється 3 традиційним образом козака як ідеального чоловіка, відповідального за долю країни, мужнього, сильного, вільного в усіх смислах цього поняття.

Ті соціальні типи, що виникають в українському суспільстві під впливом історично-соціально-психологічних чинників також оцінюються за високими вимогами. Тому в творах акцентовано увагу на описах приниження заробітчанина, а також на змалюванні його зовнішнього 
вигляду як естетично непривабливого, адже в розумінні народу, людинаневільник не може виглядати гарно (внутрішня і зовнішня краса - єдині):

Ні вмивавсі, ні вгортавсі, не мав ходак,

не вбувавсі.

Не мав ходак, не вбувавсі, не мав паса,

не впасавсі [2, с. 67].

Мотиви змарнування краси під час служби на чужих людей, від тяжкої праці та поганого харчування, як і від туги за родиною, батьківщиною - провідні в заробітчанській пісні. Крім цього, народ убачає тісний зв'язок між рабським становищем людини та формуванням у неї відповідних психологічних ознак (покірність, терплячість). Особистість, яка дозволяє себе принижувати, не може оцінюватися позитивно: Куди хилять, та й хилюся, То я всіх боюся [2, с. 174]; Один каже: «Женіть мене, я буду робить...» Другий каже: «Найміть мене, я буду служить» [2, с. 176]; - Робитиму, годитиму Пожалують люди [2, с. 173].

Картини фізичного та морального приниження заробітчанина широко представлені в пісенному фольклорі: Бідний наймит пасе воли та й нічого не знає, А йому ся з сорок мисок на обід зливає [2, с. 173]; Приймай, жінко, вареники з столу, Бо йде наймитюга [2, с. 178]; Ой кошу я сиру траву, а суху лишаю, Та мені ся із голоду діди привиджають [2, с. 176]; Богач слугу так корняє, щуо кури не піли, Дає слузі тото їсти, щзо діти не з '̈ли [2, с. 176].

Претензії й бажання героїв пісні щодо власного становища не сягають вище вимог нормального харчування, вчасного розрахунку за роботу, полегшення умов праці. Це умови, які забезпечують життя на рівні існування. Життєво необхідні чинники діяльності козака (воля, гідність, суспільна активність) втрачають свою актуальність у названих соціальних типів. Заробітчанин не відповідає народному уявленню про цілісну особистість, він економічно та психологічно не здатний створити нормальну родину, стати справжнім господарем, адже сформувався в середовищі людей, які часто 3 дитинства змушені були прислужувати іншим: $A$ з-за гори високої дощик зажурився, $A$ з дворака не господар, хоч би й оженився [2, с. 78].

Подекуди натрапляємо на твори, які ілюструють спроби відстояти власну гідність. У таких зразках протест набирає цілком відвертих форм: Ми до краю дополемо, Прикажчика поборемо, Одежу порвемо, Голову поб'ємо Що внашого пана Ряба кобила Бодай () Н. Г. Мельник, 2012. 
тебе прикончила Лихая година! [2, с. 131].

На жаль, подібні зразки - вияв поодинокості, ситуативності сплесків соціальної та особистої активності. Така поведінка не є типовою для соціального середовища заробітчанства. Як правило, характер протесту, відображається словами: «Ой ізтиха, помаленьки, най ніхто не чує».

Категорія комічного відіграє в названому циклі фольклорних творів важливу художню роль. Гостре висміювання зовнішнього вигляду утискувачів - один із засобів протесту: Од куріня до куріня ряба жаба лізла.. А в нашого пригінчого голова облізла. Од куріня до куріня доріженька проста... А в нашого пригінчого напала короста [2, с. 126]; Од кореня до кореня Чорна курка здохла, А в нашого пана Права рука всохла [2, с. 127]; Йа в нашого пана вродливая пані, Вродливая пані корова в жупані. Йа в нашого пана вродливї дочки, Вродливї дочки сідають як квочки. Йа в нашого пана вродливї сини [2, с. 135].

Ще однією гілкою творів про заробітчанство є цикл пісень про працю на цукрових заводах, ливарнях та шахтах. Вони малочисельні, порівняно 3 бурлацькими, наймитськими та емігрантськими: «Нечисленність заробітчанських пісень про роботу на заводах, шахтах пояснюється тим, що заробітчанство в умовах капіталізму тривало порівняно недовго. Для фольклору це був надто малий час, щоб події встигли в ньому широко та глибоко закарбуватися» [2, с. 27].

Мотиви цих пісень - близькі до бурлацьких та наймитських. Часто в творах головного персонажа названо бурлаком. Це логічно, адже змінилася лише назва соціального типу, а робота, ставлення до людини-заробітчанина залишилося таким, як i бурлацькому та наймитському середовищі.

Робота на заводі сприймається народом як невільницький труд: А мій милий у неволі - У сахарному заводі [2, с. 486]; Ваш муж у заводі, Він робить, роботає: Да бере топор да й рубає. А топор до рук прикипає, $A$ nіт очі заливає, А хазяйн його лає Да малих діток научає [2, с. 487]; Ой да милий у заводі, Ой на каторжній да роботі [2, c. 494].

Тяжкі умови праці, приниження від власників заводів - провідні в пісні: Ми в заводі побували - Мого горя повидали. Нам і голод нам $i$ холод, Нам і хліба не дают [2, с. 504]; На роботу буде рано, Хліба-солі дає мало. На роботу ідемо - Сухарики гриземо. Із роботи ідемо Гіркі сльози ллємо [2, с. 504].

Народна творчість ілюструє спроби протестувати проти такого 
становища заробітчанина, але цей протест обмежується лише рішенням більше не приходити на таку працю: «На другий год не прийдем, і собаки не пришлем, і сусідам закажем» [2, с. 506].

Робота на шахтах супроводжувалася травматичними ситуаціями, широко описаними народним генієм у свої творах. Провідний настрій робітничої пісні - трагічний. Часто твір починається словами: «В шахту спускається - 3 світом прощається» [2, с. 514].

Пісня насичена страшними натуралістичними картинами каліцтв на шахті і містить осмислення тяжкої долі шахтаря, який, розуміючи небезпеку, змушений щодня ризикувати життям: Доля проклятая - Така ти важка і гірка [2, с. 515]; Ой яка ж гірка ти, Судьбино шахтарська! [2, с. 515].

Фольклористи вказують на близькість українських заробітчанських пісень капіталістичної доби із російськими, адже «українські селяни виходили на заробітки в міста і села центральних районів Росії, а російські - на Україну» [1, с. 26].

Науковці також зазначають, що «у порівнянні 3 давніми заробітчанськими піснями, де переважали мінорні тони, де соціальний протест виявлявся ще досить слабо, в нових піснях емоційна палітра більш контрастна» [1, с. 27].

Отже, нові робітничі пісні про роботу на заводах та шахтах ілюструють зміни в світогляді людини-заробітчанина, який вже здатний відстояти власну гідність.

Емігрантська пісня відображає світогляд, внутрішні почуття заробітчанина, який перебуває в соціальних та етнографічних умовах, відмінних від традиційних, усталених, унормованих. Твори названої тематики надзвичайно інформативні, оскільки є джерелом пізнання побуту, особливостей життя людини поза межами батьківщини. Водночас емігрантська пісенність відображає позаматеріальні чинники, без яких представник певної нації не може почувати себе щасливим. С. Грица називає цикл емігрантських пісень «драматичною епопеєю про знедолених шукачів «земного раю», життя яких сповнене тривог, надій, соціальних і моральних утисків, розчарувань» [2, с. 27].

Масова еміграція до Угорщини, Прусії, Америки, Канади, Бразилії була викликана нестерпним економічним та психологічним становищем, яке склалося на Західній Україні в середовищі зубожілого селянства. Емігрантська пісня ілюструє спробу народу осягнути значущість традиційного, національного в житті людини. Цей масив конденсує в собі

๑ Н. Г. Мельник, 2012. 
філософсько-естетичні роздуми про неможливість гармонійного існування особистості поза межами своєї культури та складність іiі самореалізації в умовах іншої ментальності, порушує проблеми собітотожності, відповідності психічних рис людині певної нації.

Дослідження традиційних засад емігрантської пісенності цінне 3 огляду на необхідність виховання національно орієнтованого покоління українців, яке б осмислено сприяло економічному та духовному розвиткові рідної країни.

Фольклористи визначають одним із джерел виникнення емігрантської пісні попереджувальні листи, які писали селяни 3 чужини, зрозумівши оманливість своїх надій та безперспективність життя в еміграції.

Твори названої тематики відображають народний аналіз причин, які змушують людину шукати щастя за межами рідної землі. Одним із найважливіших поштовхів до еміграції було прагнення матеріального забезпечення родини: Ой Канадо, чужий краю, знайдеш, де нас діти? Бо ми в себе на рідному не маєм чим жити [2, с. 407]; Мислю іти у Канаду, а вас полишити. Я вас лишу в старім краю, сам піду в Канаду, Там зароблю трохи грошей, а може й пропаду [2, с. 408]; Ой хотів я тих доларів много заробити Та аж потім до дівчини скоренько спішити [2, с. 407].

Поряд із бажанням заробити, причиною еміграції в пісні постає прагнення досягти певної особистої свободи. Втративши надію бути вільною на батьківщині, людина спрямовує свою енергію на пошук свободи на чужині: Вже пропало, вже не будем панків цุюлювати. $B$ Бразилї нема того дурного звичаю, Щоб ся руки цюлювати, - тут того не знают. Бо тут би ся бразиляни з того насмівали, Якби тутка одні других в руки иңюлювали. Нема того і не буде, не повинно бути, 3 а такії дурні речі вже нам час забути [2, с. 409]; Мо’ далеко в Бразиліі буде ліпше жити. Тут спокійно іще жити, ніхто не здирає, Та секвестер на подвір'я ще не заглідає. Тут шандаря не забачим ніколи на очі, Тут так кождий поступає, як си кому хоче [2, с. 406].

Уміння цінувати рідне, традиційне набирає в емігрантській пісенності моральної валідності, в той час як бажання залишити батьківщину, навіть із причин цілком вмотивованих, викликає в народному середовищі засудження. Поряд із розумінням безвихідності становища селянина, змушеного від'іжджати в чужі краї, народна творчість визначає поштовхом до мандрівки прагнення «легкого 
хліба». Небажання важко працювати на батьківщині часто в пісні трактується як зрада, за яку може покарати доля: Не хтіли-сте шанувати житненького хліба - Тепер мовчи, ніи не кажи, чого тобі біда! [2, с. 432]; Тут не хтіли наші жінки припічка білити. Тепер мусять по-ииганськи на плацу палити. Тут не хтіли наші діти хатів замітати, Тепер мусять в деревляних будах привикати [2, с. 432].

Провідний настрій сцен, які змальовують від'їзд заробітчанина трагічний: Гори мої високї, мушу вас лишати. Волів би-м був у вас гнити, як в чужині жити! [2, с. 403]; Ой поїдем в Аргентину, поїдем у гості. То залишим в Аргентині свої білі кості [2, с. 412]; Бувай здоров, бувай здоров, зелений лісочку, Бо вже більще тут не вчуєш мого голосочку [2, с. 402]; Як піду з того села, зовсім заберуся, Та най верба грушки родить, а я не вернуся [2, с. 402]; Прощайте мня, добрі люди, може, з ким сварився! Прощзай мене, рідне село, церков, наша мати Господь знає, чи ся верну до тебе вмирати [2, с. 403].

Подекуди в пісні зустрічаються сподівання на щасливу долю на чужині, проте, такі твори нечисленні.

Поняття «горе», «біда», «злидні» як іпостасі гіркої долі провідні в емігрантській пісні. Поряд із абстрактними чинниками бездольного життя заробітчанина, у творах зустрічаємо й цілком конкретні: тяжкі умови праці, відсутність гарантій безпеки життя призводили до втрати здоров'я, каліцтва, що ставало причиною подальших нещасть. Наприклад: Ой Канадо, Канадочко, бодай ти пропала, Що молодість $i$ здоров'я від мене забрала [2, с. 423]; Ей, ота Америка бодай ізгоріла, Бо вна моє здоров'ячко навіки їз '̈ла [2, с. 435]; Не дай, боже, таке щастя, яке в мене було.Від тяжкої роботи мене перегнуло. Прийщов додому без доларів, няньо й мамо в гробі, А Марійка віддалася, сирота я собі [2, с. 444]; Прогуляла-м літа свої, світом вандруючи, Вернула-м ся додомочку, кровльов кашляючи [2, с. 456].

Рішення про від'їзд за кордон оцінюється народною свідомістю як вибір на користь морального чи аморального. Селянин, позбавлений зв'язків із домівкою, часто втрачав моральні орієнтири. Довга розлука 3 родиною, за піснею, викликає зміну ціннісних засад, деградацію і врешті призводить до розпаду сімейних стосунків. Наприклад: $\mathrm{He} \epsilon$, боже, не є, як младой невесие, Муж їй в Америиі, она робит иүо хие. Муж їи в Америці робить на таляри, А она купує парубкам сигари [2, с. 443]; Маю мужа в Америиі, десять літ немає, Ні до мене, ні до дітей вже ся не признає. Мої діти рідненькї, тато вас не знає, Бо наш 
тато в Америці другу маму має [2, с. 455]; Добре тому в Гамерице, хто ма жінки дві: Сдна в краю при звичаю, а друга при мні [2, с. 456]; Ми їм гроши шлеме, Гроши дулярами, Наши жінки піют Дома з фраїрами [2, с. 444]; Ой Канадо, Канадонько, яка ти зрадлива! Не їдного чоловіка з жінков розлучила. Чоловіка розлучила, дітям тата вкрала, Ой бодай ти, Канадочко, була ся зогнила [2, с. 425].

Образ батьківщини в емігрантській пісні набирає рис ідеалізації. Саме рідна земля, іiі традиції є критерієм оцінки звичаїв інших країв. Побутові деталі життя, рідні краєвиди, традиційні норми поведінки в родині та суспільстві отримують у творах названої тематики особливої ваги, етико-естетичного забарвлення: Буковино, моя мила, дорогий мій краю, Я на тебе, сиротину, нишком поглядаю, То заплачу на весь голос на чужій сторонці. В'яну я та висихаю, як листок на сонці [2, с. 444]; Ні стежечки, ні доріжечки - Все ліс та вода. Куди гляну та подивлюся: Не рід - чужина [2, с. 432]; У нас, у краю, по садочках, Скрізь птички співають, А в Канаді лиш комарі, Як гади кусають [2, с. 480]; Ой співав би-м коломийки, коби їх удати, Но я $в$ чужій сторононьці - будуть ся сміяти. Бо то чужа сторононька та чужії люде, Будуть з мене ся міяти, а мені жаль буде [2, с. 432].

Традиційною для емігрантської пісні є народна оцінка праці на чужині як рабської. Національна свідомість об'єктивно висвітлює статус емігранта як дешевої робочої сили, безправної, позбавленої нормальних умов життя, маргінальної особистості: Не мож вже мене питати ні брат, ні сестриці, Бо ми, раби з Буковини, чужі чужениці [2, с. 432]; Ой Канадо, Канадочко і ти Манітобо, Жиє в тобі руський нарід, мов тая худоба [2, с. 423]; Тут гадають наші люди, щуо будуть панами, А вони тут на роботу всі ідуть з торбами [2, с. 412]; Ой пішов я по Канаді гроші заробляти, $A$ в Канаді із голоду треба умирати [2, с. 423].

Рабське становище - естетично неприйнятне для персонажа пісні.

Виходячи 3 аналізу явищ суспільного та духовного буття, спираючись на традиційні уявлення, народна свідомість визначає формулу оцінки емігрантства: «Вандрівництво - ізрадництво, вандрівництво - горе». Провідною ідеєю пісні є думка: «Не виїжджайте до тої страшної біди». Народна творчість ілюструє впевненість у тому, що кожна людина повинна забезпечувати свої матеріальні та духовні потреби у власній державі, в межах рідної культури.

Проаналізований матеріал дає підстави зробити висновок про те, що 
формування національних світоглядних засад - динамічний процес, що передбачає трансформацію традиційних оцінок дійсності в залежності від історичних, політичних та суспільних умов. Глибоке осмислення народом соціальних процесів, матеріальних та духовних чинників формування особистості сприяло виникненню широкого пласту пісенних творів, які відображають емоції та почуття людини в дисгармонійних обставинах.

Проблеми, що їх висвітлює фольклорна спадщина заробітчанської тематики, набирають особливої актуальності сьогодні, у часи переоцінки традиційних світоглядних засад.

Отже, традиційні уявлення про місце людини в суспільному житті та в родині, сформовані в козацькому середовищі зазнають трансформацій в соціальних прошарках заробітчан. Бурлацька та наймитська пісня відображає реакції особистості на стан невільництва, засуджує пасивність, покірність, здатність до рабського приниження. Комічне у творах постає виявом негативної оцінки явищ та поведінки людей. Гостре висміювання зовнішнього вигляду утискувачів - один із засобів стихійного протесту, що супроводжує ситуацію непримирення особистості із власним рабським становищем, здатність «наївно» протистояти статусу невільника.

Емігрантська пісня утверджує народне переконання в тому, що людина, позбавлена рідного мікрокосму, стає національно та морально дезорієнтованою, загубленою, втрачає ознаки своєї духовної сутності. Розчарування, безнадія, відчування себе чужим і німим рабом провідні мотиви названого циклу. Життя на батьківщині, працю на рідній землі осмислюються народною творчістю як необхідні чинники повноцінного розвитку особистості, складові ії цілісності.

\section{Література}

1. Грица С. Й. Наймитські та заробітчанські пісні / С. Й. Грица / Наймитські та заробітчанські пісні. - К. : Наукова думка, 1975. - С. 9-44.

2. Наймитські та заробітчанські пісні / [Упоряд. С. Й. Грица, О. І. Дей, М. Г. Марченко]. - К. : Наукова думка, 1975. - 576 с.

3. Соціально-побутові пісні / [Упоряд., вступна стаття та примітки О. М. Хмілевської]. - К. : Дніпро, 1985. - 331 с.

4. Скрипка В. М. Спільні мотиви громадсько-побутових пісень українців, чехів і словаків / В. М. Скрипка // НТЕ. - 1963. - №4. - С. 81-88. 